\title{
Examining the Effect of Automatic Promotion on Students' Learning Achievements in Uganda's Primary Education
}

\author{
Jeje Moses Okurut ${ }^{1, *}$ \\ ${ }^{1}$ Graduate School of International Cooperation Studies, Kobe University, Kobe City, Japan \\ *Correspondence: Takeda Apartment 1F North, Kamimaecho 3-3-3, Kobe-shi, Nada-ku, Hyogo-ken, 657-0052, \\ Japan. Tel: 81-80-3848-8524. E-mail: jeje.okmo@yahoo.co.uk
}

Received: July 20, 2015

doi:10.5430/wje.v5n5p85
Accepted: September 2, $2015 \quad$ Online Published: October 11, 2015

URL: http://dx.doi.org/10.5430/wje.v5n5p85

\begin{abstract}
This study employed a difference-in-differences analysis technique to estimate the average treatment effect of automatic promotion on students' cognitive learning outcomes in Uganda's primary education. Regression results indicate a positive policy effect on learning achievements in literacy and numeracy at primary three (P3) and primary six (P6). Specifically, the implementation of automatic promotion policy has translated in to an increase in learning outcomes in reading and mathematics at P3 and P6, all statistically significant at conventional levels. Decomposing the effect along gender and school location (rural or urban) dimensions reveals positive and statistically significant effect on literacy and numeracy in both grades. The effect on students' scores in rural areas is higher than that on students' in urban schools. In terms of gender, the effect is relatively similar for female students and their male counterparts. These results are contrary to the popular belief among many Ugandans, but consistent with earlier scholarly works that have attributed automatic promotion with positive impact on learning outcomes.
\end{abstract}

Keywords: automatic promotion; students' learning achievements; difference-in-differences

\section{Introduction}

\subsection{Background}

The practice of allowing students to progress from one class to the next irrespective of their academic performance otherwise called automatic promotion, has polarized education development stakeholders along the lines of those in support and those against. According to Steiner (1986), the origin of the policy can be traced to the 1930s and it is adopted and implemented in the perceived interest of a student's social and psychological well-being. Arguments for and against automatic promotion are centered on its credibility as a viable alternative to grade retention, in the search for efficiency and better learning outcomes. Empirical and non-empirical studies conducted in both developed and developing countries to estimate the impact of automatic promotion policy and that of grade retention policy on students' learning achievements show mixed and inconclusive results. Arguments in support for the policy as a better alternative to grade retention fall into three broad categories namely; enhancing education quality, improving internal efficiency of education and personal development of students/learners.

Enhancing the quality of education arguments point to the fact that repetition does not improve the achievement of the low-achiever, nor does it reduce the range of abilities, since each grade will carry the retained student into the next year as a source of a difference in ability (Ndaruhustse, 2008; and Peterson et al., 1987). Moreover, retaining students leads to crowding in classrooms, leading to high student-classroom ratios and high student-teacher ratios thus lowering the overall quality of education (Chimombo, 2005). By contrast, automatic promotion fosters equity in learning outcomes especially between male and female students (Ndaruhustse, 2008) and between rural-urban settings (Chen et al., 2010; and McCoy \& Reynolds, 1999). In developing countries, female students and students in rural schools tend to register lower learning outcomes, compared to their respective counterparts.

In terms of improving internal efficiency of education, the arguments highlight the policy's ability to save costs for both governments and households since it reduces if not eliminates, grade repetition, increases survival and completion rates by reducing student dropout rates, and increases the number of years low achieving students spend in school (Mehrotra, 1998; Verspoor, 2006; and Ndaruhutse, 2008). Regarding personal development of learners, 
grade repetition is noted as having adverse effect on students' self-esteem and motivation (Xia \& Kirby, 2009). Likewise, retention stigmatizes students and impairs their natural ability to relate with their peers. This more often than not culminates into alienation of the students in question, thus resulting in eventual exiting of the schooling cycle (Holmes, 1989). Furthermore, repeating grades prolongs the actual school completion time as well as time to engage productively in the labor market, which represents a monetary cost to students over their life-cycles (Eide \& Showalter, 2001).

Counter arguments against automatic promotion state that it negatively affects the overall quality of education since it eliminates competition, de-motivates students and teachers alike hence lowering teaching and learning outcomes (Koppensteiner, 2014; Taye, 2003; and Chohan \& Qadir, 2011). By contrast, grade retention is viewed as leading to an improvement in cognitive learning outcomes (Brophy, 2006; Roderick et al., 2002; and King et al., 1999). It is worth noting that studies that have reported academic gains attributable to repetition have gone on to add that the gains are short-term and as a result eventually retained students end up lagging behind, which affects their self-esteem and increases the probability of dropping out (Brophy, 2006; and Jimerson et al., 1997).

\subsection{Ugandan Context}

Uganda adopted and implemented the automatic promotion policy in 2005 as an interventionist strategy aimed at enhancing the internal efficiency and quality of primary education. Implying that it was and is still targeted at eliminating if not reducing grade repetition, reducing school dropout, improving pedagogical duration and efficacy, hence improving learning outcomes (see also Ndaruhutse, 2008). Improvements in internal efficiency and quality of education in turn enhance the achievement of Education For All (EFA) goals and Millennium Development Goals (MDGs), especially EFA goals 2, 5 and 6, and MDGs 2 and 3. The policy is implemented only in government primary schools because internal inefficiencies in terms of high repetition rate, high dropout rate, low survival rate and low completion rate were on average higher among them. Moreover, government schools form the bulk of primary schools in the country $(12,203$ out of 18,079) and implement Universal Primary Education (UPE), thus high inefficiencies imply wastage of money for both the government and households, as well as time for the students. Under the UPE program, government pays tuition for all students enrolled in UPE implementing schools and parents meet costs related to scholastic materials such as school uniform, pens, pencils, exercise books, school meals and so forth. Thus when a child repeats a grade/ grades or drops out of the primary schooling cycle, it represents wastage of not only financial resources for both entities (government and households), but time for students since they will take relatively longer to graduate and enter the workforce (see also Chimombo, 2005; Eide \& Showalter, 2001).

As already alluded to, the adoption and subsequent implementation of automatic promotion came on the back of high internal inefficiency prevailing within the primary education sub-sector, coupled with low quality of education. Inefficiency manifested itself through high repetition and dropout rates, which by 2004 were recorded at approximately $35 \%$ and $21 \%$ respectively (EMIS, 2010). The low quality of education was reflected by low academic achievements at all primary grades, and characterized by disparities along gender and rural-urban dimensions. For instance, according to National Assessment of Progress in Education (NAPE) 2004, pass rates for English and mathematics at primary three (P3) were respectively $37 \%$ and $44 \%$ and even lower for primary six (P6), $25 \%$ and $27 \%$ respectively. By 2010 these rates had improved, albeit still below regional and international averages. While literacy and numeracy at P3 improved to 57\% and 72\% respectively, at P6 they had improved to 50\% and $54 \%$ respectively. Uganda's, learning outcomes in terms of gender and rural-urban dimensions are lower among female students by approximately 5 percentage points (Nannyonjo, 2007; and Kasirye, 2009) and rural areas by approximately 15 percentage points (Kagoda, 2012; and Nannyonjo, 2007). In the Sub-Saharan Africa context, Zhang (2006) and Ndaruhutse (2008) likewise acknowledge the existence and persistence of these disparities.

\subsection{Problem Statement}

Since its adoption and implementation, automatic promotion has given rise to an engaging debate amongst education stakeholders in Uganda. The policy is supported by the Ministry of Education and Sports (MoES) and international education development partners (donors) operating in the country. The opponents of the policy comprise parents, school administrators, district education officials, private education providers, and Non-Government Organizations (NGOs). The arguments for and against the policy in Uganda are similar to those held in developed and other developing countries that have experience with it (i.e. contrasting it with grade retention). The difference being that the debate in Uganda is happening without either side presenting any evidence in the context of Uganda to support their respective claims/arguments. The MoES and education development partners for example base their arguments on positive experiences from other countries that have adopted and implemented the policy, which though basically acceptable, represents an over generalization. Different countries have different education systems and levels of 
education development, so simply assuming what worked or is working in one country/ region will automatically work in another is a gross misrepresentation. The opponents on their part simply blame the policy for the inefficiencies and low quality of education still prevailing in the primary education sub-sector, without any proof. They also point to the fact that no prior sensitization and/or awareness creation was conducted among the various stakeholders on the relevance and necessity of the policy before its subsequent implementation.

Moreover, previous studies on quality and efficiency of primary education in Uganda including but not limited to the studies by Muvawala (2012), Ogawa et al. (2011), Tamusuza (2011), Byamugisha (2010), Kasirye (2009), Nishimura \& Ogawa (2009), Okumu et al. (2008) and Nannyonjo (2007), have made no reference to the policy at all and those that have, simply report it as potentially leading to either lower or better learning outcomes, but without any empirical evidence. For instance Nannyonjo (2007); and Nishimura \& Ogawa (2009) both simply mention automatic promotion even though it was not the main focus of their respective studies. In particular, Nannyonjo (2007) argues in favor of the policy as potentially being good for Uganda, while Nishimura \& Ogawa (2009) cite discontent towards it among sampled parents. Muvawala (2012); Ogawa et al. (2011); Byamugisha (2010); and Kasirye (2009) examined factors affecting learning outcomes in Uganda's primary education, but make no mention and/ or reference to automatic promotion. Tamusuza (2011); and Okumu et al. (2008) focused on the determinants of school dropout in Uganda, but likewise make no reference to the policy. On the international scene, some of the scholarly works that have investigated the impact of automatic promotion include; Chohan \& Qadir (2011); Fonkeng (2006); and Taye (2003), who employed qualitative approach to explore the impact of automatic promotion on learning outcomes at primary level in Pakistan, Cameroon and Ethiopia respectively. These studies documented only opinions and views of the respondents (teachers) in the three countries regarding the policy and its impact. Koppensteiner (2014) examined the effect of automatic grade promotion on students' performance in Brazil, using a difference in differences approach. However, his analysis focused on $4^{\text {th }}$ grade students and did not assess effect incidence along gender and school location dimensions.

\subsection{Purpose and Research Questions}

Given the above mixed and inconclusive discussion, coupled with the lack of national empirical evidence either for or against the policy, this study thus seeks to fill the information gap regarding the impact of automatic promotion on students learning achievements in Uganda. This impact estimation extends to capture effect incidence on female and male students, as well as students in rural and urban schools. This is important since it highlights the effectiveness of the policy in terms of fostering equity in learning outcomes. Moreover, automatic promotion operates efficiently and effectively in complement with other factors that contribute to better teaching and learning outcomes (sees also Ndaruhutse, 2008; Roderick \& Nagaoka, 2005; and Palafox et al., 1994). Some of these factors are gender specific, others are rural-urban specific and some overlap between the two. Therefore by highlighting the incidence of the effect in the context of Uganda, this study helps draw attention from the currently narrow narrative that equates learning achievements as a function of only automatic promotion, to a broader and deeper focus on the factors affecting teaching and learning at the primary level of education.

Consequently, the key research question guiding this study is; what is the effect of automatic promotion on students' learning achievements in Uganda's primary education? To assess the incidence of the effect along gender and school location, this study responds to the following sub-research questions. First, what is the effect of automatic promotion practice on learning achievements of students in rural areas and those in urban settings? Second, what is the effect of automatic promotion practice on learning achievements of female and male students? The answers to these research questions demonstrate the effectiveness of the policy, a key requirement in the field of policy analysis for purposes of knowing whether the policy is working. If not, why not? If yes, in which area or category of people? How can it be improved? This line of analysis is relevant from the point of view of Uganda's primary education, given that the policy was adopted to ensure both male and female students stay in school and learn, whether in rural or urban settings. The remainder of the paper is structured as follows. Section 3 contains a review of previous studies, section 4 entails the methodology adopted, including theoretical framework, analysis technique, data and sources. Section 5 presents the results and discussion of the impact assessment and section 6 is the conclusion.

\subsection{Review of Previous Studies}

This section takes stock of some of the earlier research works reviewed in the debate on the pros and cons of both automatic promotion and grade retention. Myung et al. (2013) found that students who are retained in grades 1 to 5 perform in middle schools as well as their propensity matched, continuously promoted peers, both academically and in terms of behavioral engagement and feeling part of the school. Retention did not appear to offer any advantage to these students, nor did it impede their performance in middle school. Reschly \& Christenson (2013) argued that 
grade retention and automatic promotion are often portrayed as a dichotomy, though this portrayal is a simplification of the issue. According to them, at the center of this debate, is the question of what to do with students who are not meeting academic and behavioral standards. In their opinion, it is vital that struggling learners receive carefully monitored instruction and supplemental interventions that address their learning needs.

Ndaruhutse (2008) found that repetition had negative effects on children's learning achievement, attendance record, personal adjustment in school and attitude towards school as they advanced to the next grade. On average, retained students are worse off than their counterparts in both personal adjustment and academic outcomes. She adds that; countries with policies of automatic promotion produced higher results in reading compared to those that practice repetition. Jimerson in his 2007 study concluded that grade retention, when compared with automatic promotion of similar children, is an ineffective and possibly harmful intervention. Promotion plus, which involves combining grade promotion and effective evidence-based interventions is most likely to benefit children with low achievement or behavior problems. Manacorda (2006), in his study on grade retention and dropout in Uruguay, found that grade retention leads to lower educational attainment 4 to 5 years after the time when failure first occurred. Silberglitt et al. (2006) used longitudinal analyses and revealed that grade retention did not yield advantages in reading trajectories from first- to eighth-grade. In particular, the results indicated that; compared to their prior growth rate, retained students did not experience either a benefit or deficit in their growth rate during the repeated year. Compared to similarly performing promoted students, retained students did not experience any benefit or deficit in their growth rates as a result of retention; and the growth curve of the randomly selected group was significantly greater than the progress of the retained students.

Brophy (2006) also noted that grade repetition leads to relative and temporary improvement in learning achievement, though this outcome should not be such a surprise precisely because the repeating students are literally a year older and are working through the same curriculum for the second time. Grade repetition does not provide more general advances in knowledge or cognitive skills that would enable them to make more satisfactory achievement progress in subsequent grades. Hong \& Raudenbush (2005) found a null and very small average effect of the kindergarten retention policy, as compared to a policy that banned retention. They found no evidence that the policy would benefit those children who would be promoted if the policy were adopted, though they found evidence that children who were retained would have learned more had they been promoted. This was true in both reading and math.

McCoy \& Reynolds (1999) indicated that grade retention is at best an insufficient intervention strategy for promoting student achievement, at least for many children in urban, metropolitan areas such as Chicago. In their view, the major implication is that grade retention does not appear to benefit many of the children it is designed to help. Holmes (1989) found that when promoted and retained students were compared one to three years later, the retained students' average levels of academic achievement were at least 0.4 standard deviations below those of promoted students. Peterson et al (1987) indicated that retention does not have a favorable long-term impact on the academic achievement of primary students as measured by relative class standing in the same year. This is especially true considering that promoted students scored nearly as well as retained students by the third year after retention, but they were taking a test that was one grade level higher than the retained students and thus were answering questions concerning more advanced material.

Contrary to the above scholars, Koppensteiner (2014) in his study on the relationship between automatic promotion and learning achievements in Brazil found a negative and significant effect of about $6 \%$ of a standard deviation. Findings by Taye (2003) on the impact of automatic promotion on learning outcomes in Ethiopia showed that $90.4 \%$ of the teachers interviewed said grade retention is better than automatic promotion to help underachieving students perform better in latter grades. Chohan and Qadir (2011) employed qualitative method to explore the impact of automatic promotion policy on the quality of education and found a negative impact. Furthermore, Greene and Winters (2006) found that after two years of the policy, retained students in Florida made significant reading gains relative to the control group of socially promoted students. These academic benefits grew substantially from the first to the second year after retention.

In terms of rural urban discourse, a study by Chen X. et al (2010) on grade retention and school performance in poor areas in rural China showed that there is no positive effect of grade retention on school performance of the students that were retained in rural areas. Whether in the short term or longer term, they reject the hypothesis that grade retention improves the scores of the students that were retained. This result is true for students that were retained in grade 2, grade 3 and grade 4 . In fact, in the analysis of some students that were retained grade retention was shown to have a statistically significant and negative effect on school performance. Terry (2011) while examining the beliefs of kindergarten through fourth grade teachers regarding effects of retention on academic, emotional, and social areas, 
as well as alternative interventions to retention in a rural school in Ohio - USA, found that teachers felt that grade retention is an appropriate intervention for students and that retention has very a negative effect on a student's future socially or academically. This is despite the strong empirical evidence against grade retention and calls for automatic promotion.

Battistin and Schizzerotto (2012) investigated the effect of grade retention on student achievement among upper secondary schools in Italy and concluded that the reform had a negative effect on motivation and engagement of the most struggling students, thus exacerbating existing inequalities. In particular, they observed negative effects for female students in technical and vocational schools, for both reading and science test scores. Westbury (1994) stated that males are far more likely than females to repeat an elementary school grade, with the gender difference persisting when achievement is controlled. Meisels and Liaw (1993) examined the phenomenon of retention in kindergarten through Grade 8. They found that retention does not equalize outcomes even when retained students have been in school a year longer. In particular, they asserted that retention is associated with more negative outcomes for female, White, and higher SES students.

\section{Methodology}

\subsection{Theoretical Framework}

This study is structured within the human capital theory, which attributes increased productivity of individuals (male or female either in rural or urban areas) to education and training, as a result of acquiring relevant skills and knowledge. Increased productivity ultimately raises workers' future income and their lifetime earnings. Literature on human capital theory identifies different types and/ or means of education and these are formal education (primary, secondary and higher levels of education), non-formal education, on the job training and specialized vocational education (Becker, 1964). Human capital theory thus suggests that individuals and society derive economic benefits from investing in people primarily through education (Sweetland, 1996). According to Boissiere (2004), education is the cornerstone of economic growth and social development, and primary education provides the foundation for secondary and tertiary education and training, and lays the foundation for a more productive labor force through promoting literacy and numeracy.

In this regard, countries all over the world (developed and developing, including Uganda) strive to maximize human capital development by investing in primary education and education in general. In order to promote efficiency and effectiveness of these investments, governments have and continue to implement various policy initiatives. In the case of Uganda, one such policy is the automatic promotion policy, which seeks to enhance efficiency in the provision of quality primary education. This study therefore highlights the impact of automatic promotion on students' learning achievements in the country. Proficiency in literacy and numeracy at the primary level is a reliable predictor of students' acquisition of foundational skills and knowledge required for future personal and socio-economic development.

\subsection{Analysis Technique/ Model}

The technique used to estimate the effect of automatic promotion on students' cognitive learning achievements, is the Difference in Differences (D-i-D) approach. This approach is a quasi-experimental method used in econometrics to estimate the effect of a treatment or intervention at a given period in time. The simplest set up is one where outcomes are observed for two groups for two time periods. While one of the groups is exposed to the treatment in the second period but not in the first period, the other is not exposed to the treatment in either period.

The use of D-i-D method became very widespread in the field of evaluating the impact of a policy or program, especially after research work by Ashenfelter and Card (1985). Other early scholars greatly associated with this estimation method include Card and Krueger (1994), Meyer (1995), and Hastings (2004). As mentioned above, D-i-D assumes two groups (treatment and control) and two time periods (pre-treatment and post-treatment), such that outcomes of the two groups are observed during the two periods. The treatment group is exposed to the treatment in the post-treatment (second) period but not in the pre-treatment (first) period. The control group is not exposed to the treatment in either period. In cases where the same units within each group are observed in each time period, then average gain in the control group is subtracted from the average gain in the treatment group. This removes biases in second period comparisons between the treatment and control groups that could be a result of permanent differences between those groups, as well as biases from comparisons over time in the treatment group that could be a result of trends. D-i-D is applicable with either experimental data or non-experimental (observational) data.

In the context of this study, the treatment is automatic promotion, implemented only in government primary schools 
(not in private schools), implying that the control group is comprised of students from private schools and the treated group is comprised of students from government schools. The decision to use students as the unit of analysis instead of schools (private and government) was taken because ultimately the policy is geared towards ensuring that students stay in the primary schooling cycle so as to be able to gain knowledge and skills required for their academic and personal development. It is the students who are taught and assessed, who repeat classes and who drop out of the schooling cycle, so evaluating the policy effect at this level is critical for future policy decisions. This line of analysis is further justified by the fact that international commitments on education (EFA Goals and MDGs), whose achievement the policy is meant to enhance, target learners (male \& female) whether in rural or urban settings for purposes of ensuring sustainable socio-economic development.

The adoption of D-i-D method was dictated primarily by the nature of the dataset available and the methods ability to minimize if not eliminate any biases that might arise from permanent latent differences between treatment and control groups as well as biases resulting from common trends overtime. Therefore, whilst students from government and private schools are respectively the treatment and control groups, years 2004 and 2010 represent the before and after time element. The two groups are indexed by treatment status $(\boldsymbol{S}=\mathbf{1 , 0})$, whereby $\boldsymbol{S}=\mathbf{1}$ indicates students who received treatment and $\boldsymbol{S}=\mathbf{0}$ indicates students who did not receive the treatment. Students' learning achievements is denoted by $\boldsymbol{Y}$ and observed over two time periods $(\boldsymbol{T}=\mathbf{1 , 0})$ where $\boldsymbol{T}=\boldsymbol{1}$ indicates a time period after the treated group received treatment and $\boldsymbol{T}=\boldsymbol{0}$ indicates a time period before the treated group received treatment. In addition, every student observed in either group pre and post treatment is indexed by the letter $i=1, \ldots, N$, so that individuals will typically have two observations each, one pre-treatment and one post-treatment. With either repeated cross sections or experimental data, the D-i-D model for a generic member of any of the groups can be written as shown in equation 1.

$$
Y_{i t}=\beta_{0}+\beta_{1} S_{i}+\beta_{2} T_{t}+\beta_{3}\left(S_{i} * T_{t}\right)+\varepsilon_{i t}
$$

Where $\boldsymbol{Y}_{i t}$ is the outcome variable of interest, $\boldsymbol{T}_{t}$ is a dummy variable for the second time period, $\boldsymbol{S}_{\boldsymbol{i}}$ is a dummy variable for treatment status. $\boldsymbol{S}_{i}$ captures possible differences between the treatment and control groups prior to the policy change and $\boldsymbol{T}_{\boldsymbol{t}}$ captures aggregate factors that would cause changes in $\boldsymbol{Y}_{i t}$ even in the absence of a policy change. The coefficient of interest, $\boldsymbol{\beta}_{3}$ multiplies the interaction term, $\boldsymbol{S}_{i} * \boldsymbol{T}_{\boldsymbol{t}}$ which is the same as a dummy variable equal to one for those observations in the treatment group in the second period. The coefficients given by $\boldsymbol{\beta}_{0}, \boldsymbol{\beta}_{1}, \boldsymbol{\beta}_{2}$, $\boldsymbol{\beta}_{3}$, are all unknown parameters and $\boldsymbol{\varepsilon}_{i t}$ is a random, unobserved "error" term which contains all determinants of $\boldsymbol{Y}_{i t}$ which the model omits. The coefficients have the following interpretation; $\boldsymbol{\beta}_{0}=$ constant term, $\boldsymbol{\beta}_{1}=$ captures time-invariant difference in overall means between two groups, $\boldsymbol{\beta}_{2}=$ captures the time trend common to control and treatment groups, $\boldsymbol{\beta}_{3}=$ true effect of treatment.

Under the D-i-D framework, causality is inferred when the parallel assumption holds, depending on whether it is experimental or non-experimental data. The assumption posits that the average change in the outcome variable for the treated in the absence of treatment is equal to the observed change in the outcome variable for the control group. If experimental data is used during analysis, then a simple comparison of the mean of the outcome in the treatment and control groups is justified on grounds that randomization guarantees they should not have any systematic differences in any other pre-treatment variable (Morgan \& Winship, 2012; Angrist \& Krueger, 1999; Meyer, 1995). On the other hand, if non-experimental data is used, as is the case in this study then the parallel assumption requires that in the absence of treatment, the difference between treatment and control groups is relatively stable over time, since randomization is not guaranteed (Angrist \& Pischke, 2008; Antonakis et al., 2010; Murnane \& Willet, 2011). In this study, allocation to treatment status among the treated group (government schools) and control group (private schools) was not random and as such randomization is not guaranteed. There are differences and similarities between the two groups, which are relatively stable over time. Stability of the trend between government and private schools is supplemented by the fact that selection of schools and students to participate in the assessment was randomly carried out. Bertrand, Duflo, and Mullainathan (2003), discuss extensively the problem of serial correlation in D-i-D estimates arrived at using time series and/ or pooled cross-sections datasets. The existence of autocorrelation was tested using Breusch-Godfrey test (estat bgodfrey, lag (1)), and found not to exist (no autocorrelation correlation). Given the observational data, equation 1 was modified accordingly to control for observable school, teacher, student and household covariates, such that D-i-D framework takes the structure illustrated by equation 2 .

$$
y_{i t}=\beta_{0}+\beta_{1} S_{i}+\beta_{2} T_{t}+\beta_{3}\left(S_{i} * T_{t}\right)+\beta_{4} \delta+\beta_{5} \varphi+\varepsilon_{i t}
$$

The Greek small letter delta $\delta$ represents school and teacher explanatory variables and the Greek small letter phi $\varphi$ represents student and household explanatory variables. Then taking expectation of the outcome variable $y$ given the 
treatment status (treated and control), treatment period (pre-treatment and post-treatment) \& selected explanatory variables, leads to equation 3 .

$$
E\left[Y_{i t} \mid S_{i}, T_{t}, \delta, \varphi\right]=\left(\beta_{0}+\beta_{1} S_{i}+\beta_{2} T_{t}+\beta_{3}\left(S_{i} * T_{t}\right)+\beta_{4} \delta+\beta_{5} \varphi+\varepsilon_{i t}\right)
$$

Whereby;

$$
\begin{gathered}
E[y \mid S=1, T=1, \delta, \varphi]=\left(\beta_{0}+\beta_{1}+\beta_{2}+\beta_{3}+\beta_{4}+\beta_{5}\right) \\
E[y \mid S=1, T=0, \delta, \varphi]=\left(\beta_{0}+\beta_{2}+\beta_{4}+\beta_{5}\right) \\
E[y \mid S=0, T=0, \delta, \varphi]=\left(\beta_{0}+\beta_{1}+\beta_{4}+\beta_{5}\right) \\
E[y \mid S=0, T=1, \delta, \varphi]=\left(\beta_{0}+\beta_{4}+\beta_{5}\right)
\end{gathered}
$$

Therefore the Difference in Differences (DID) estimator is given by;

$E[y \mid S=1, T=1, \delta, \varphi]-E[y \mid S=1, T=0, \delta, \varphi]-E[y \mid S=0, T=1, \delta, \varphi]-E[y \mid S=0, T=0, \delta, \varphi]$

$\left(\beta_{0}+\beta_{1}+\beta_{2}+\beta_{3}+\beta_{4}+\beta_{5}\right)-\left(\beta_{0}+\beta_{2}+\beta_{4}+\beta_{5}\right)-\left(\beta_{0}+\beta_{4}+\beta_{5}\right)-\left(\beta_{0}+\beta_{1}+\beta_{4}+\beta_{5}\right)$

Implying that $\mathrm{D}$-i-D estimator $=\boldsymbol{\beta}_{3}$

\subsection{Data Description}

The study employed two non-experimental (pooled cross-sections) datasets. The first is the National Assessment of Progress in Education (NAPE) for the years 2004 and 2010. NAPE is managed and administered for and on behalf of the MoES by a semi-autonomous institution called Uganda National Examination Board (UNEB). The assessment was first conducted in 1999 and has continued to be conducted every year at primary education to randomly selected schools and students. It contains learning achievements in literacy (English) and numeracy (Mathematics) and covariates related to schools, teachers and students. Literacy and numeracy scores in both grades are standardized at 100 percentage points, with a student deemed proficient if he/ she, scores a minimum of 40 percentage points in a particular subject. The assessment is conducted in primary three (P3) and primary six (P6) in order to ascertain the level of students' learning outcomes at lower primary and upper primary respectively, and to monitor changes in the achievement levels over time, thus allowing for any necessary remedial measures to be implemented. While P3 marks the end of lower primary (upper primary transition), P6 though not the final grade of primary schooling in Uganda, represents the end of upper primary. The P7 (actual final grade in Primary) candidates are exempted from NAPE because they have to prepare for the national lower secondary transition exam.

The two grades (P3 \& P6) were considered during this policy evaluation in order to estimate its impact on learning achievements at lower primary and upper primary, especially considering the fact that the age composition of the students and curriculum content in the two grades are different. As already highlighted in the introduction, automatic promotion does not operate in isolation and as such understanding its effect in this grades helps draw attention towards complementary factors influencing learning outcomes. The official primary school enrolment age for primary one (P1) is 6 years old and that of completing primary seven (P7) is 12 years old. Implying that, a student in P3 is supposed to be 8 years old and a student in P6 is supposed to be 11 years old, however, there are cases of underage and overage enrolment throughout the primary schooling cycle.

The sampling design used in the process of collecting NAPE data is a two-stage stratified cluster. The first stage involves selecting a random sample of schools stratified by district, with all the districts in the country being included in the sample frame. In the second stage, random samples of students present in the school on the day of the survey are then selected from P3 \& P6. From each district a minimum of 10 primary schools are sampled and from each school a simple random sample of 20 students (male and female) are selected per class. At P3 the total number of observations (students) tested were 27,653, of which 19,265 students were from government schools and 8,388 from private schools. At P6 the total number of observations tested was 27,413, of which 8,316 were from private schools and 19,097 were from government schools. During the analysis, the actual number of observations used was 26,835 for students in P3 and 26,413 for students in P6, after eliminating missing values and outliers through a data cleaning process.

The second data set is from Uganda Bureau of Statistics (UBOS), called Uganda National Household Survey (UNHS) for the years 2004 and 2010. UNHS likewise adopts a two-stage stratified sampling design. In the first stage, Enumeration Areas (EAs) are grouped by districts and rural-urban location; then drawn using Probability Proportional to Size (PPS). At the second stage, households which are the ultimate sampling units are drawn using 
systematic sampling. The two data sets (NAPE and UNHS) were merged and subsequently analyzed using Stata data analysis and statistical software version 13 . These data sets provide a backdrop against which an empirical estimation of the effect of automatic promotion on students' learning achievements was carried out. In particular, NAPE provided the dependent variable (learning achievements) and covariates related to schools, students and teachers, and UNHS provided information on household variables. Tables 1 and 2 portray descriptive statistics for the variables used during analysis.

Table 1. Dependent and Independents Variables Used to Analyze the Effect of AP at P3

\begin{tabular}{|c|c|c|c|c|c|}
\hline Variables & Obs & $\begin{array}{l}\text { Mean or } \\
\text { Proportion }\end{array}$ & Std. Dev. & Min & Max \\
\hline \multicolumn{6}{|l|}{ Outcome Variable } \\
\hline Literacy Score (in percentage) & 26835 & 45.10092 & 22.28487 & 0 & 100 \\
\hline Numeracy Score (in percentage) & 26835 & 55.71201 & 21.82946 & 0 & 100 \\
\hline \multicolumn{6}{|l|}{ Exogenous Variables } \\
\hline Post2005 (1= Post Treatment) & 26835 & 0.7204938 & 0.4487641 & 0 & 1 \\
\hline Treatmentstatus ( $1=$ Treated Schools $)$ & 26835 & 0.7052233 & 0.2547746 & 0 & 1 \\
\hline Interactionterm ( $1=$ Treated $\&$ Post Treatment $)$ & 26835 & 0.6694839 & 0.4704068 & 0 & 1 \\
\hline \multicolumn{6}{|l|}{ School and Teacher Variables } \\
\hline Location (1= Rural) & 26835 & 0.7319462 & 0.4695123 & 0 & 1 \\
\hline Distance to nearest Market $(\mathrm{Km})$ & 26835 & 2.162047 & 3.994293 & 1 & 15 \\
\hline School Feeding Program (Mid-day) & 26835 & 1.206937 & 0.4771973 & 1 & 3 \\
\hline Teacher Education (Level) & 26835 & 3.306264 & 1.008662 & 1 & 5 \\
\hline Teacher Experience (Years) & 26835 & 9.579145 & 6.420587 & 1 & 31 \\
\hline Teacher Absenteeism & 26835 & 2.336018 & 0.6098313 & 1 & 5 \\
\hline \multicolumn{6}{|l|}{ Student and Household Variables } \\
\hline Gender $(1=$ Male $)$ & 26835 & 0.512661 & 0.499848 & 0 & 1 \\
\hline Age in Years & 26835 & 10.57338 & 1.580671 & 5 & 20 \\
\hline Student Repeated Class or Classes & 26835 & 1.759658 & 0.8554717 & 1 & 4 \\
\hline Student Absenteeism $(\mathrm{Yes}=1)$ & 26835 & 0.9960403 & 0.0628023 & 0 & 1 \\
\hline Student Receives Homework & 26835 & 3.218935 & 0.9170761 & 1 & 4 \\
\hline Student Receives Homework Corrections & 26835 & 3.705777 & 1.176349 & 1 & 5 \\
\hline Mothers Education (Level) & 26835 & 2.739959 & 1.036803 & 1 & 5 \\
\hline Fathers Education (Level) & 26835 & 2.612418 & 1.130686 & 1 & 5 \\
\hline No of Children in Household (Siblings) & 26835 & 1.423419 & 1.162823 & 0 & 6 \\
\hline Distance from Home to School & 26835 & 3.814042 & 0.255717 & 0 & 11 \\
\hline Household Expend on Education (US\$(Note)) & 26835 & 41.26442 & 172.61272 & 0 & 6566 \\
\hline
\end{tabular}

Source: Created by Author using NAPE (2004 \& 2010) and UNHS (2004 \& 2010)

Note: Uganda's currency is called Ugandan Shilling and the international code is UGX. The average exchange rate between the US\$ \& UGX in 2004 was 1:1,700 and that of 2010 was 2,490. To adjust for inflation between 2004 and 2010, I used Consumer Price Indexes (CPIs) for the two years. According to Bank of Uganda (BoU) website, the CPI for 2004 was 92.21 and that of 2010 was 149.97. 
Table 2. Dependent and Independent Variables Used to Analyze the Effect of AP at P6

\begin{tabular}{|c|c|c|c|c|c|}
\hline Variables & Obs & $\begin{array}{l}\text { Mean or } \\
\text { Proportion }\end{array}$ & Std. Dev. & Min & Max \\
\hline \multicolumn{6}{|l|}{ Outcome Variables } \\
\hline Literacy Score (in percentage) & 26413 & 41.87358 & 20.89814 & 0 & 100 \\
\hline Numeracy Score (in percentage) & 26413 & 47.15012 & 19.27435 & 0 & 100 \\
\hline \multicolumn{6}{|l|}{ Exogenous Variables } \\
\hline Post2005 (1= Post Treatment) & 26413 & 0.7199864 & 0.4490141 & 0 & 1 \\
\hline Treatmentstatus ( $1=$ Treated Schools $)$ & 26413 & 0.6981032 & 0.4590894 & 0 & 1 \\
\hline Interactionterm $\quad(1=$ Treated \& Post Treatment $)$ & 26413 & 0.5231287 & 0.4998791 & 0 & 1 \\
\hline \multicolumn{6}{|l|}{ School and Teacher Variables } \\
\hline Location (1=Rural) & 26413 & 0.7224094 & 0.4478188 & 0 & 1 \\
\hline Distance to nearest Market $(\mathrm{Km})$ & 26413 & 1.80574 & 1.927116 & 1 & 15 \\
\hline School Feeding Program (Mid-day) & 26413 & 1.205929 & 0.4752283 & 1 & 3 \\
\hline Teacher's Education (Level) & 26413 & 3.31036 & 1.010984 & 1 & 5 \\
\hline Teacher's Experience (Years) & 26413 & 9.540291 & 6.413295 & 1 & 31 \\
\hline Teacher Absenteeism & 26413 & 2.33352 & 0.6124514 & 1 & 3 \\
\hline \multicolumn{6}{|l|}{ Student and Household variables } \\
\hline Gender & 26413 & 0.5587779 & 0.4965425 & 0 & 1 \\
\hline Age in Years & 26413 & 13.77384 & 1.459634 & 9 & 27 \\
\hline Student Repeated a Class/ Classes & 26413 & 1.75988 & 0.8562059 & 1 & 4 \\
\hline Student Absenteeism & 26413 & 0.9961383 & 0.0620239 & 0 & 1 \\
\hline Student Receives Homework & 26413 & 3.221631 & 0.9189553 & 1 & 4 \\
\hline Student Receives Homework Corrections & 26413 & 3.711572 & 1.178228 & 1 & 5 \\
\hline Mothers Education (Level) & 26413 & 2.742328 & 1.043092 & 1 & 5 \\
\hline Fathers Education (Level) & 26413 & 2.617028 & 1.136788 & 1 & 5 \\
\hline No. of Children in a Household & 26413 & 1.409874 & 1.162359 & 0 & 6 \\
\hline Distance from Home to School & 26413 & 3.814042 & 0.255717 & 0 & 11 \\
\hline Household Total Expend on Education (US\$) & 26413 & 41.26442 & 172.61272 & 0 & 6566 \\
\hline
\end{tabular}

Source: Created by Author using NAPE (2004 \& 2010) and UNHS (2004 \& 2010)

\section{Results and Discussion}

The regression results presented here are from equation (2) specified in the methodology section. The results are structured according to the research questions such that sub-section 3.1 titled automatic promotion and students' learning achievements illustrates the overall treatment effect in response to the main research question, and sub sub-sections 3.1.2 and 3.1.2 respectively contain the breakdown of the effect along the two dimensions referenced by the two sub-research questions.

\subsection{Automatic Promotion and Students' Learning Achievements}

Table 3 illustrates the OLS regression results of the impact of implementing automatic promotion policy on students' learning achievements at P3 and P6. Columns 1 and 3 show a positive and statistically significant effect of approximately $9 \%$ and $10 \%$ on literacy and numeracy at P3. At P6 the effect is approximately $7 \%$ for literacy, and $5 \%$ for numeracy. These results are statistically significant, as shown in columns 5 and 7 respectively. 
Table 3. Effect of Automatic Promotion on Literacy and Numeracy Scores at P3 and P6

\begin{tabular}{|c|c|c|c|c|c|c|c|c|}
\hline \multirow[t]{4}{*}{ Variables } & \multicolumn{4}{|c|}{ P3 } & \multicolumn{4}{|c|}{ P6 } \\
\hline & \multicolumn{2}{|c|}{ Literacy } & \multicolumn{2}{|c|}{ Numeracy } & \multicolumn{2}{|c|}{ Literacy } & \multicolumn{2}{|c|}{ Numeracy } \\
\hline & Coef. & $\mathbf{t}$ & Coef. & $\mathbf{T}$ & Coef. & $\mathbf{T}$ & Coef. & $\mathbf{t}$ \\
\hline & (1) & (2) & (3) & (4) & (5) & (6) & (7) & (8) \\
\hline Post2005 & $\begin{array}{l}6.797 * * * \\
(1.029)\end{array}$ & 6.61 & $\begin{array}{l}3.634 * * * \\
(1.112)\end{array}$ & 3.27 & $\begin{array}{l}8.067 * * * \\
(0.614)\end{array}$ & 13.14 & $\begin{array}{l}7.802 * * * \\
(0.527)\end{array}$ & 14.80 \\
\hline Treatmentstatus & $\begin{array}{l}-31.695 * * * \\
(0.959)\end{array}$ & -33.05 & $\begin{array}{l}-28.064 * * * \\
(1.014)\end{array}$ & -27.68 & $\begin{array}{l}-26.025 * * * \\
(0.661)\end{array}$ & -39.37 & $\begin{array}{l}-24.250 * * * \\
(0.562)\end{array}$ & -43.15 \\
\hline Interactionterm & $\begin{array}{l}9.291 * * * \\
(1.094)\end{array}$ & 8.49 & $\begin{array}{l}10.092^{* * * *} \\
(1.034)\end{array}$ & 9.76 & $\begin{array}{l}6.843 * * * \\
(0.710)\end{array}$ & 9.64 & $\begin{array}{l}4.730 * * * \\
(0.662)\end{array}$ & 7.15 \\
\hline Constant & $\begin{array}{l}78.332 * * * \\
(16.781)\end{array}$ & 4.67 & $\begin{array}{l}69.023 * * * \\
(9.323)\end{array}$ & 7.40 & $\begin{array}{l}38.772 * * * \\
(9.952)\end{array}$ & 3.89 & $\begin{array}{l}34.390 * * * \\
(6.408)\end{array}$ & 5.37 \\
\hline $\mathrm{N}$ & 26835 & & 26835 & & 26413 & & 26413 & \\
\hline Adj. R-Sq & 0.323 & & 0.387 & & 0.330 & & 0.395 & \\
\hline
\end{tabular}

Robust standard errors in parentheses

$* * * \mathrm{p}<0.01, * * \mathrm{p}<0.05, * \mathrm{p}<0.1$

These findings are consistent with Ndaruhutse (2008) who found that countries implementing automatic promotion (including Sub-Saharan Africa countries) produced higher learning results compared with those that practice repetition. However, the results are contrary to Koppensteiner (2014) who found a negative and significant effect on $4^{\text {th }}$ grade learning achievements of about $6 \%$ of a standard deviation attributed to automatic grade promotion in Brazil. One of the possible reasons for the difference in the effect at P3 and P6 is the difference in students' school/ classroom attendance patterns. P6 students are older and as such are more likely to have household chores (cooking, attending to the sick and so forth), as well as helping generate income to supplement that of the household head, which makes their attendance very irregular compared to P3 students. This is not only the reality in Uganda, especially in rural locations, but a view held by earlier scholars such as Ndaruhutse (2008) and Chimombo (2005).

\subsubsection{Effect on Rural and Urban Learning Achievements at P3 and P6.}

The first sub-research question sought to ascertain the effect of implementing the policy on learning outcomes of P3 and P6 students studying in rural and urban primary schools. Table 4 shows P3 literacy in rural and urban settings as having increased by about $9 \%$ and $12 \%$ respectively (see columns 1 and 3 ), all statistically significant at standard levels. This represents a $3 \%$ difference in the effect on urban and rural literacy in primary schools. As regards numeracy scores at P3, columns 2 and 4 show the implementation of automatic promotion resulted in an increase of approximately $12 \%$ and $11 \%$ for students in rural and urban schools respectively, implying $1 \%$ difference.

Table 4. Effect of Automatic Promotion on Rural and Urban Learning Achievements at P3 and P6

\begin{tabular}{|c|c|c|c|c|c|c|c|c|}
\hline \multirow[b]{3}{*}{ Variables } & \multicolumn{4}{|c|}{ P3 } & \multicolumn{4}{|c|}{ P6 } \\
\hline & \multicolumn{2}{|c|}{ Rural } & \multicolumn{2}{|c|}{ Urban } & \multicolumn{2}{|c|}{ Rural } & \multicolumn{2}{|c|}{ Urban } \\
\hline & $\begin{array}{c}\text { Literacy } \\
\text { (1) }\end{array}$ & $\begin{array}{c}\text { Numeracy } \\
\text { (2) } \\
\end{array}$ & $\begin{array}{c}\text { Literacy } \\
\text { (3) }\end{array}$ & $\begin{array}{c}\text { Numeracy } \\
\text { (4) }\end{array}$ & $\begin{array}{c}\text { Literacy } \\
\text { (5) }\end{array}$ & $\begin{array}{c}\text { Numeracy } \\
(6) \\
\end{array}$ & $\begin{array}{c}\text { Literacy } \\
(7)\end{array}$ & $\begin{array}{c}\text { Numeracy } \\
\text { (8) } \\
\end{array}$ \\
\hline Post2005 & $\begin{array}{l}0.361 \\
(2.172)\end{array}$ & $\begin{array}{l}2.209 \\
(1.931)\end{array}$ & $\begin{array}{l}5.340 * * * \\
(1.338)\end{array}$ & $\begin{array}{l}2.037 \\
(1.281)\end{array}$ & $\begin{array}{l}-6.552 * * * \\
(1.165)\end{array}$ & $\begin{array}{l}-0.596 \\
(1.045)\end{array}$ & $\begin{array}{l}19.194 * * * \\
(1.724)\end{array}$ & $\begin{array}{l}12.351 * * * \\
(1.559)\end{array}$ \\
\hline Treatmentstatus & $\begin{array}{l}-36.229 * * * \\
(2.149)\end{array}$ & $\begin{array}{l}-30.776^{* * *} \\
(2.033)\end{array}$ & $\begin{array}{l}-34.323^{* * *} \\
(1.139)\end{array}$ & $\begin{array}{l}-31.221 * * * \\
(1.076)\end{array}$ & $\begin{array}{l}-34.360 * * * \\
(1.225)\end{array}$ & $\begin{array}{l}-23.758^{* * *} \\
(1.102)\end{array}$ & $\begin{array}{l}-29.016^{* * *} \\
(1.282)\end{array}$ & $\begin{array}{l}-20.864 * * * \\
(1.159)\end{array}$ \\
\hline Interactionterm & $\begin{array}{l}8.712 * * * \\
(2.297)\end{array}$ & $\begin{array}{l}12.453 * * * \\
(2.028)\end{array}$ & $\begin{array}{l}12.411^{* * *} \\
(1.478)\end{array}$ & $\begin{array}{l}11.345^{* * *} \\
(1.414)\end{array}$ & $\begin{array}{l}10.561 * * * \\
(1.301)\end{array}$ & $\begin{array}{l}9.099 * * * \\
(1.173)\end{array}$ & $\begin{array}{l}6.029 * * * \\
(1.794)\end{array}$ & $\begin{array}{l}7.310 * * * \\
(1.620)\end{array}$ \\
\hline Constant & $\begin{array}{l}84.394 * * * \\
(11.898)\end{array}$ & $\begin{array}{l}86.199 * * * \\
(11.722)\end{array}$ & $\begin{array}{l}82.320^{* * *} \\
(5.708)\end{array}$ & $\begin{array}{l}77.926 * * * \\
(5.299)\end{array}$ & $\begin{array}{l}63.125^{* * *} \\
(7.469)\end{array}$ & $\begin{array}{l}62.420 * * * \\
(7.944)\end{array}$ & $\begin{array}{l}61.338 * * * \\
(6.549)\end{array}$ & $\begin{array}{l}57.006^{* * *} \\
(5.921)\end{array}$ \\
\hline $\mathrm{N}$ & 19590 & 19590 & 7245 & 7245 & 19011 & 19011 & 7402 & 7402 \\
\hline Adj. R-Sq. & 0.388 & 0.369 & 0.378 & 0.332 & 0.357 & 0.368 & 0.339 & 0.375 \\
\hline
\end{tabular}

Robust standard errors in parentheses

$* * * \mathrm{p}<0.01, * * \mathrm{p}<0.05, * \mathrm{p}<0.1$ 
At P6, regression results for both literacy and numeracy are likewise statistically significant at conventional levels. The rural literacy score increased by approximately $11 \%$ and the urban literacy score by $6 \%$, as shown in columns 5 and 7. In the same grade, columns 6 and 8 indicate that urban and rural numeracy scores experienced increases of approximately $7 \%$ and $9 \%$ respectively. One of the possible reasons for the rural-urban difference at P3 is that in Uganda, as in other countries (developed and developing) parents in urban communities generally tend to be more active and supportive towards the education of their children during early grades. These results are consistent with Chen et al. (2010) and Ndaruhutse (2008) who report no improvements in learning outcomes in rural areas of China and Sub-Saharan Africa respectively, as a result of grade retention and as such argue in favor of automatic promotion.

At P6, a higher impact on learning achievements among students in rural schools relative to those in urban schools is contrary to findings by Gomes-Neto and Hanushek (1994), and El-Hassan (1998) who found higher learning achievements in urban areas of Brazil and Lebanon. In the local Ugandan context, possible reasons explaining the pro-rural difference include improved community participation in the form of functional school management committees (SMCs), coupled with support supervision for school administrators and teachers by center coordinating tutors (CCTs) in rural schools. These functions are generally at a lower level in rural schools relative to urban once, however, over the last 10 or so years, the government has made concerted attempts to address the imbalance.

\subsubsection{Effect on Male and Female Learning Achievements at P3 and P6}

In response to the second sub-research question, the incidence of the effect on the gender component was estimated and the regression results are contained in Table 5. From columns 1 and 3, it can be noted that female and male literacy scores at $\mathrm{P} 3$ have increased by about $7 \%$ and $6 \%$ respectively, implying $1 \%$ difference. Numeracy scores for both sexes at P3 increased by about $10 \%$ each as shown in columns 2 and 4 . The effect along gender lines at P6 shows that, the literacy score for both sexes increased by approximately $7 \%$ (columns 5 and 7 ). Regarding numeracy, girls' score increased by about $6 \%$ and boys' increased by about $4 \%$, as shown in columns 6 and 8 . This represents $2 \%$ difference in numeracy learning outcomes between girls and boys.

Table 5. Effect of Automatic Promotion on Female and Male Learning Achievements at P3 and P6

\begin{tabular}{|c|c|c|c|c|c|c|c|c|}
\hline \multirow[b]{3}{*}{ Variables } & \multicolumn{4}{|c|}{ P3 } & \multicolumn{4}{|c|}{ P6 } \\
\hline & \multicolumn{2}{|c|}{ Female } & \multicolumn{2}{|c|}{ Male } & \multicolumn{2}{|c|}{ Female } & \multicolumn{2}{|c|}{ Male } \\
\hline & $\begin{array}{c}\text { Literacy } \\
\text { (1) } \\
\end{array}$ & $\begin{array}{c}\text { Numeracy } \\
\text { (2) }\end{array}$ & $\begin{array}{c}\text { Literacy } \\
\text { (3) } \\
\end{array}$ & $\begin{array}{c}\text { Numeracy } \\
\text { (4) }\end{array}$ & $\begin{array}{c}\text { Literacy } \\
\text { (5) }\end{array}$ & $\begin{array}{c}\text { Numeracy } \\
\text { (6) }\end{array}$ & $\begin{array}{c}\text { Literacy } \\
(7)\end{array}$ & $\begin{array}{c}\text { Numeracy } \\
\text { (8) }\end{array}$ \\
\hline \multirow[t]{2}{*}{ Post2005 } & $4.925 * * *$ & 1.723 & $4.492 * * *$ & $3.325 * *$ & 1.064 & $5.547 * *$ & $5.110 * * *$ & $6.643 * * *$ \\
\hline & $(1.481)$ & $(1.463)$ & $(1.374)$ & $(1.374)$ & $(2.420)$ & $(2.239)$ & $(1.439)$ & $(1.342)$ \\
\hline \multirow[t]{2}{*}{ Treatmentstatus } & $-37.606 * * *$ & $-31.972 * * *$ & $-34.749 * * *$ & $-29.437 * * *$ & $-31.084 * * *$ & $-22.183 * * *$ & $-29.913 * * *$ & $-21.992 * * *$ \\
\hline & $(1.310)$ & $(1.294)$ & $(1.215)$ & $(1.216)$ & $(2.370)$ & $(2.193)$ & $(1.234)$ & $(1.150)$ \\
\hline \multirow[t]{2}{*}{ Interactionterm } & $6.927 * * *$ & $9.760 * * *$ & $6.461 * * *$ & $10.362 * * *$ & $6.591 * * *$ & $5.511 * *$ & $7.429 * * *$ & $5.486 * * *$ \\
\hline & $(1.534)$ & $(1.508)$ & $(1.422)$ & $(1.417)$ & $(2.490)$ & $(2.305)$ & $(1.461)$ & $(1.413)$ \\
\hline \multirow[t]{2}{*}{ Constant } & $72.542 * * *$ & $76.876^{* * *}$ & $65.053 * * *$ & $69.297 * * *$ & $44.350 * * *$ & $42.761 * * *$ & $62.362 * * *$ & $61.357 * * *$ \\
\hline & $(4.083)$ & $(4.032)$ & $(3.778)$ & $(3.780)$ & $(14.660)$ & $(13.571)$ & $(3.896)$ & $(3.632)$ \\
\hline $\mathrm{N}$ & 13150 & 13150 & 13685 & 13685 & 12942 & 12942 & 13471 & 13471 \\
\hline Adj. R-Sq. & 0.380 & 0.341 & 0.368 & 0.351 & 0.394 & 0.381 & 0.326 & 0.302 \\
\hline
\end{tabular}

Robust standard errors in parentheses

$* * * \mathrm{p}<0.01, * * \mathrm{p}<0.05, * \mathrm{p}<0.1$

The effect of the policy along gender lines in both grades, as indicated in columns 1 to 8 of Table 5 , is relatively similar. The possible reasons for the similarity in the impact include; the use of the same curriculum, instructional textbooks and pedagogy. In addition, the schools have basic facilities and/ or infrastructure relevant to teaching and learning, such as classrooms, latrines, desks and benches, and so forth. Moreover, household/ community involvement through SMC activities likewise possibly explain the similarity. These results are consistent with Varol and Yilmaz (2010) who likewise noted similarities between female and male learners' autonomous behaviors in relation to reading flashcards and making suggestions to the teacher about in-class language learning tasks. 


\section{Limitations of the Study}

Firstly, assignment to treatment and control groups was not randomly carried out, since the government simply announced the introduction of automatic promotion in public schools and not private schools. Moreover, control and treated groups have differences (e.g., students' background characteristics, class sizes) and similarities (e.g., same curriculum, teachers trained in same teachers' colleges, same grading and assessment system), which it must be noted, are relatively stable over time, thus allowing for plausible causal inference (Antonakis et al., 2010). Stability of the trend between government and private schools is supplemented by the fact that selection of schools and students' to participate in the annual national assessment is randomly carried out (NAPE, 2010).

Finally, the data sets used were not collected for the purpose of assessing the impact of automatic promotion policy. Thus there are inadequacies within the data in terms of other key variables that impact learning outcomes. In the context of this study some variables such as students' and teachers' attendance and actual teaching time are missing, meaning that the estimated effect of the policy justifiably attracts some critical reviews. Given enough time and resources, data specifically geared towards evaluating the policy and its impact on Uganda's primary education quality and efficiency would be more insightful.

\section{Policy Implications}

The overall goal of this study was to empirically estimate the effect of automatic promotion on students' cognitive learning achievements as one of the measures of education quality. Estimation results reveal a positive effect on P3 and P6 learning achievements measured in terms of literacy and numeracy. When the effect incidence is disaggregated along gender and rural-urban components, the effect is still positive and statistically significant. Within conventional standards, these results indicate the effectiveness of the policy as one of the strategies for improving students' learning achievements. Moreover, consideration of equity in the context of male and female students as well as school location (rural or urban) demonstrates the policy as being effective. These findings are contrary to popular belief in Uganda, but similar to those demonstrated by earlier studies on automatic promotion and grade retention. The belief among most Ugandans is that automatic promotion has contributed to the worsening of the quality of not only primary education, but education as a whole in the country.

On the basis of these findings, two policy implications emerge. Firstly, there is a need for the government and education development partners in the country to conduct awareness campaign for the public about automatic promotion, why it is necessary and relevant for the long term provision and development of education in Uganda. One of the issues emerging (based on print and electronic media in Uganda) is the absence of prior consultations and awareness campaigns and/ or programs on the relevance, strengths and weaknesses of automatic promotion policy, targeted at the various stakeholders. The need for extensive consultation and awareness creation programs cannot be emphasized enough, especially given the fact that since the start of formal education in the country in the 1890s, a "merit based" system of promotion operated until 2005 when automatic promotion was adopted. Therefore, parents, teachers and administrators (national, local government/ district and school level) are all products of the performance based promotion system. In the absence of comprehensive policy consultation and adequate public awareness campaigns, it's plausible that the opponents to the policy in Uganda are rallying against change in the education system, which they do not fully understand.

Secondly and coupled with the above is the need for the government and education development partners (donors) to assess the existence and adequacy of other factors or variables that influence the quality of education. This is because automatic promotion does not operate in isolation, but rather complements other equally vital components in provision and development of education. A number of these factors overlap the two components (gender and school location), some are gender specific and others are rural - urban specific. Examples of other equally important factors complementary with policy include the following teachers' salaries, teachers' accommodation, instructional material, parents/ community participation, absenteeism by both teachers and students, number of primary schools and their distribution between rural and urban settings, number of teachers, and proportion of teachers by gender (male and female), to mention but a few. Ensuring that necessary and sufficient conditions for productive teaching and learning processes are established, will in turn enhance automatic promotion practice as a viable option.

\section{Acknowledgements}

I'm very grateful to my academic supervisor, Prof. Keiichi Ogawa for the constant motivation and encouragement he rendered me during the entire process of writing this paper. Special gratitude goes to Dr. Eduardo Velez Bustillo for the detailed and insightful comments and guidance he provided during the editorial process. Finally, I wish to 
express my deepest gratitude towards Mitsubishi Corporation for the International Students Scholarship that has enabled me to pursue my doctoral studies and conduct this research.

\section{References}

Angrist, J. D., \& Pischke, J. S. (2005). Mostly harmless econometrics: An empiricist's companion. Chapter 5: Parallel Worlds: Fixed effects, differences-in-differences, and panel data, pp 221-247. http://dx.doi.org/10.1007/s00362-009-0284-y

Angrist, J. D., \& Krueger, A. B. (1999). Instrumental variables and the search for identification: From supply and demand to natural experiments. The Journal of Economic Perspectives, 15(4), 69-85. http://dx.doi.org/10.1257/jep.15.4.69

Antonakis, J., Bendahan, S., Jacquart, P., \& Lalive, R. (2010). On making causal claims: A review and recommendations. The Leadership Quarterly, 21, 1086-1120. http://dx.doi.org/10.1016/j.leaqua.2010.10.010

Ashenfelter, O., \& Card, D. (1985). Using the longitudinal structure of earnings to estimate the effects of training programs. Review of Economics and Statistics, 67, 648-660. http://dx.doi.org/10.2307/1924810

Bertrand, M., Duflo, E., \& Mullainathan, S. (2003). How much should we trust differences-in-differences estimates? The Quarterly Journal of Economics, 119(1), 249-275. http://dx.doi.org/10.1162/003355304772839588

Battistin, E., \& Schizzerotto, A. (2012). Threat of grade retention, remedial education and student achievement: Evidence from upper secondary schools in Italy. IZA, Discussion Paper No. 7086, pp 1-52. http://ftp.iza.org/dp7086.pdf

Boissiere, M. (2004). Rationale for public investments in primary education in developing countries. Background paper for the evaluation of the World Bank's support to primary education. The World Bank, pp 1-30. Retrieved from: http://ieg.worldbank.org/Data/reports/education_public_investments_wp.pdf

Brophy, J. (2006). Grade repetition. International academy for education (IAE) and UNESCO international institution for educational planning (IIEP). Education Policy Series 6, pp 1-33. Retrieved from: http://www.unesco.org/iiep/PDF/Edpol6.pdf

Byamugisha, A. (2010). Examining the effects of school environment factors on pupils' learning achievement in Uganda primary schools. African Education Research Journal, 1, 110-133. Retrieved from: https://docs.google.com/file/d/0BxjnVLC402PwajdaT0xZbTZUNHVsN1BzLVRGaU1Bdw/edit

Card, D., \& Krueger, A. (1994). Minimum wages and employment: A case study of the fast-food industry in New Jersey and Pennsylvania. The American Economic Review, 84(4), 777-793. http://dx.doi.org/10.3386/w4509

Chen, X., Liu, C., Zhang, L., Shi, Y., \& Rozelle, S. (2010). Does taking one step back get you two steps forward? Grade retention and school performance in poor areas in rural China. International Journal of Educational Development, 30(6), 544-559. http://dx.doi.org/10.1016/j.ijedudev.2009.12.002

Chimombo, J. (2005). Issues in basic education in developing countries: an exploration of policy options for improved delivery. Journal of International Cooperation in Education, 8(1), 129-152.

Chohan, B. I., \& Qadir, S. A. (2011). Automatic promotion policy at primary level and MDG-2. Journal of Research and Reflections in Education, 5(1), 1-20.

Eide, E. R., \& Showalter, M. H. (2001). The effect of grade retention on educational and labor market outcomes. Economics of Education Review, 20, 563-576. http://dx.doi.org/10.1016/s0272-7757(00)00041-8

El-hassan, K. (1998). Relation of academic history and demographic variables to grade retention. Journal of Education Research, 91(5), 279-288. http://dx.doi.org/10.1080/00220679809597555

Fonkeng, E. G. (2006). Strategies to reduce repetition in Cameroon primary schools. The University of Yaounde I, Faculty of Arts, Letters and Social Sciences, Department of Psychology, pp 1-19. Retrieved from: http://www.saga.cornell.edu/saga/educconf/fonkeng.pdf

Gomes-Neto, J. B., \& Hanushek, E. A. (1994). Causes and Consequences of Grade Repetition: Evidence from Brazil. Economic Development and Cultural Change, 43(1), 117-148. http://dx.doi.org/10.1086/452138

Green, J. P., \& Winters, M. A. (2009). The effects of exemption to Florida's test-based promotion policy: Who is retained? Who benefits academically? Economics of Education Review, 28, 13-142. http://dx.doi.org/10.1016/j.econedurev.2008.02.002 
Hastings, J. (2004). Vertical relationships and competition in retail gasoline markets: Empirical evidence from contract changes in southern California. The American Economic Review, 94(1), 317-328. http://dx.doi.org/10.1257/000282804322970823

Holmes, C. T. (1989). Grade level retention effects: A meta-analysis of research studies. In L. Shepard \& M. Smith (Eds.), Flunking grades: Research and policies on retention, London: Falmer Press, pp 16-34. Retrieved from: http://www.colorado.edu/education/sites/default/files/attached-files/Flunking\%20Grades.pdf

Hong, G., \& Raudenbush, W. S. (2005). Effects of kindergarten retention policy on children's cognitive growth in reading and mathematics. Educational Evaluation and Policy Analysis, 27, 205-224. http://dx.doi.org/10.3102/01623737027003205

Jimerson, S. R., Anderson, G. E., \& Whipple, A. D. (2002). Winning the battle and losing the war: Examining the relation between grade retention and dropping out of high school. Psychology in the Schools, 39(4), 441-457. http://dx.doi.org/10.1002/pits.10046

Jimerson, S. R., Carlson, E., Rotert, M., Egeland, B., \& Sroufe, L.A. (1997). A prospective, longitudinal study of the correlates and consequences of early grade retention. Journal of School Psychology, 35(1), 3-25. http://dx.doi.org/10.1016/s0022-4405(96)00033-7

Kagoda, M. (2012). Access to quality primary education in rural societies of Uganda. School of Education, Makerere University. For UN Women and UNICEF, pp 1-16. Retrieved from: https://www.worldwewant2015.org/pt-br/node/290351

Kasirye, I. (2009). Determinants of learning achievement (Grade 6) in Uganda. Economic Policy Research Centre (EPRC), Makerere University, Kampala, pp 1-39. Retrieved from: http://www.csae.ox.ac.uk/conferences/2009-edia/papers/325-kasirye.pdf

Kavaliauskiene, G. (2009). Role of mother tongue in learning English for specific purposes. ESP World Issue 1 (22), 8, 1-12. Retrieved from: http://www.esp-world.info/Articles_22/PDF/ROLE\%20OF\%20MOTHER\%20TONGUE\%20IN\%20LEARNIN G\%20ENGLISH\%20FOR\%20SPECIFIC\%20PURPOSES.pdf

Khejeri, M. (2013). Effect of English on the teaching and use of mother tongue in lower primary schools in Hamisi district, Kenya. Research Journal in Organizational Psychology \& Educational Studies, 2(6), 317-324. Retrieved from: http://rjopes.emergingresource.org/articles/EFFECT\%20OF\%20ENGLISH.pdf

King, E. M., Orazem P. F., \& Paterno E. M. (1999). Promotion with and without learning: effects on student dropout. The World Bank Development Research Group. Working Paper Series on Impact Evaluation of Education Reforms, 18, 1-28. http://dx.doi.org/10.1596/1813-9450-4722

Koppensteiner, M. F. (2014). Automatic grade promotion and student performance: Evidence from Brazil. Journal of Development Economics, 107, 277-290. http://dx.doi.org/10.1016/j.jdeveco.2013.12.007

Manacorda, M. (2006). Grade failure, drop out and subsequent school outcomes: Quasi-experimental evidence from Uruguayan administrative data. London School of Economics, 1-73. Retrieved from: http://cep.lse.ac.uk/seminarpapers/13-12-06-MAN.pdf

McCoy, A., \& Reynolds, A. (1999). Grade retention and school performance: An extended investigation. Journal of School Psychology, 37(3), 273-298. http://dx.doi.org/10.1016/s0022-4405(99)00012-6

Mehrotra, S. (1998). Education for All: Policy Lessons from High-Achieving Countries. International Review of Education, 44(5/6), 461-484. http://dx.doi.org/10.1023/a:1003433029696

Meisels, J., \& Liaw, F. (1993). Failure in grade: Do retained students catch up? The Journal of Educational Research, 87(2), 69-77. http://dx.doi.org/10.1080/00220671.1993.9941169

Meyer, B. D. (1995). Natural and quasi-experiments in economics. Journal of Business and Economic Statistics, 13(2), 151-161. http://dx.doi.org/10.1080/07350015.1995.10524589

Murnane, R. J., \& Willet, J. B. (2011). Estimating causal effects using a regression-discontinuity approach: Methods matter: Improving causal inference in educational and social science research. Oxford University Press, pp $165-202$.

Bought

from: http://www.amazon.com/Methods-Matter-Improving-Inference-Educational/dp/0199753865

Murnane, R. J., \& Willet, J. B. (2011). Dealing with bias in treatment effects estimated from non-experimental data: 
Methods matter: Improving causal inference in educational and social science research. Oxford University Press, pp $2862331 . \quad$ - 28 Bought http://www.amazon.com/Methods-Matter-Improving-Inference-Educational/dp/0199753865

Muvawala, J. (2012). Determinants of learning outcomes for primary education: A case of Uganda. The African Statistical Journal, 15, 42-54.

Myung, H., Hughes, J. N., Kwok, O., Puckett, S., \& Cerda, C. A. (2013). Effect of retention in elementary grades on transition to middle school. Journal of School Psychology, 51(3), 349-365. http://dx.doi.org/10.1016/j.jsp.2013.01.004

Nannyonjo, H. (2007). Education inputs in Uganda: an analysis of factors influencing learning achievements in grade six. African Region Human Development Series Number 98, World Bank, pp 1-89. http://dx.doi.org/10.1596/978-0-8213-7056-8

Ndaruhutse, S. (2008). Grade repetition in primary schools in Sub-Saharan Africa: An evidence base for change. Center for British Teachers (CfBT) Education Trust, pp 1-76. Retrieved from: http://www.consultasrodac.sep.gob.mx/cartilla/pdf/Grade\%20Repetition_FINAL_8FEB08.pdf

Nishimura, M., \& Ogawa, K. (2009). Universal primary education policy and quality of education in Sub-Saharan Africa: A comparative analysis of Malawi, Ghana, Kenya and Uganda and policy recommendations. Journal of International Cooperation in Education, 12(1), 143-158.

Ogawa, K., Nishimura, M., \& Byamugisha, A. (2011). Universal primary education policy and quality of education in Sub-Saharan Africa: The case study of Soroti and Kabale districts in Uganda. African Education Research Journal, Japan. No. 1, pp 60-66. Retrieved from: Kobe University Library (Hard Copy).

Okumu, I. M., Nakajjo, A., \& Isoke, D. (2008). Socioeconomic determinants of primary school dropout: the logistic model analysis. Economic Policy Research Center, Makerere University and Munich Personal RePEc Archive, pp 1-25. http://mpra.ub.uni-muenchen.de/7851/

Palafox, J. C., Prawda, J., \& Velez, E. (1994). Primary school quality in Mexico. Comparative Education Review, 38(2), 167-180. http://dx.doi.org/10.1086/447240

Peterson, S. E., DeGracie, J. S., \& Ayabe, C. R. (1987). A longitudinal study of the effects of retention/promotion on academic achievement. American Educational Research Journal, 24(1), 107-118. http://dx.doi.org/10.3102/00028312024001107

Reschly, A., \& Christenson, S. (2013). Grade retention: historical perspectives and new research. Journal of School Psychology, 51, 319-322. http://dx.doi.org/10.1016/j.jsp.2013.05.002

Roderick, M., \& Nagaoka, J. (2005). Retention under Chicago's high-stakes testing program: helpful, harmful, or harmless? Educational Evaluation and Policy Analysis, 27(4), 309-340. http://dx.doi.org/10.3102/01623737027004309

Roderick, M., Jacob, B. A., \& Bryk, A. S. (2002). The impact of high-stakes testing in Chicago on student achievement in promotional gate grades. Educational Evaluation and Policy Analysis, 24(4), 333-357. http://dx.doi.org/10.3102/01623737024004333

Silberglitt, B., Appleton, J. J., Burns, M. K., \& Jimerson, S. R. (2006). Examining the effects of grade retention on student reading performance: A longitudinal study. Journal of School Psychology, 44(4), 255-270. http://dx.doi.org/10.1016/j.jsp.2006.05.004

Sweetland, S. R. (1996). Human capital theory: Foundations of a field of inquiry. Review of Educational Research, 66(3), 341-359. http://dx.doi.org/10.3102/00346543066003341

Tamusuza, A. (2011). Leaving School Early: The quest for Universal Primary Education in Uganda. The African Statistical Journal, 13, 110-151.

Taye, D. (2003). Automatic promotion practices in the first-cycle of primary schools in west Gojjam zone. Addis Ababa University, School of Graduate Studies, pp 1-123. Retrieved from: http://www.academia.edu/2446791/AUTOMATIC_PROMOTION_PRACTICES_IN_THE_FIRST-CYCLE_O F_PRIMARY_SCHOOLS_IN_WEST_GOJJAM_ZONE

Terry, S. E. (2011). Teachers' beliefs towards grade retention in a rural elementary school. Marshall University Marshall, Digital Scholar. Theses, Dissertations and Capstones. Paper 284, pp1-36. Retrieved from: http://mds.marshall.edu/cgi/viewcontent.cgi?article=1282\&context=etd 
Varol, B., \& Yilmaz, S. (2010). Similarities and differences between female and male learners: inside and outside class autonomous language learning activities. Procedia Social and Behavioral Sciences, 3, 237-244. http://dx.doi.org/10.1016/j.sbspro.2010.07.038

Verspoor, A. (2006). Effective schools for Sub-Saharan Africa: Conditions and factors of effective schools in Africa. Paper prepared for plenary session 3 of the ADEA biennale on education in Africa, Libreville, Gabon, pp 27-31. Retrieved from: http://www.adeanet.org/portalv2/adea/biennial-2006/doc/document/PL3_1_verspoor_en.pdf

Westbury, M. (1994). The effect of elementary grade retention on subsequent school achievement and ability. Canadian Journal of Education, 19(3), 241-250. http://dx.doi.org/10.2307/1495130

Wooldridge, J. M. (2009). Heteroskedasticity. In J.W. Calhoun, M. Worls and L. Bofinger (Eds.), introductory econometrics: A modern approach. Michigan: South-Western Cengage Learning, pp. 264-293. Retrieved from: http://ncbae.yolasite.com/resources/IntroductoryEconometrics_AModernApproach_FourthEdition_Jeffrey_Woo ldridge.pdf

Wooldridge, J. M. (2009). Pooling cross sections a cross time: Simple panel data methods. In J.W. Calhoun, M. Worls and L. Bofinger (Eds.), introductory econometrics: A modern approach. Michigan: South-Western Cengage Learning, pp. 444-471. Retrieved http://ncbae.yolasite.com/resources/IntroductoryEconometrics_AModernApproach_FourthEdition_Jeffrey_Woo ldridge.pdf

Xia, N., \& Kirby, S. N. (2009). Retaining students in grade a literature review of the effects of retention on students' academic and non-academic outcomes. Rand Education, 1-31. http://dx.doi.org/10.1037/e528842010-001

Zhang, Y. (2006). Urban-rural literacy gaps in Sub-Saharan Africa: The roles of socioeconomic status and school quality. Comparative Education Review, 50(4), 581-602. http://dx.doi.org/10.1086/507056 